\title{
The Increase of Rural Economy at Baraka Sub-District through Village Funds
}

\author{
Abdul Karim ${ }^{1 *}$; Chalid Imran Musa²; Romansyah Sahabuddin ${ }^{3}$; Muhammad Azis ${ }^{4}$ \\ ${ }^{1}$ Doctoral Student in Economic Program, Universitas Negeri Makassar \\ Jl. AP. Pettarani Makassar, Sulawesi Selatan, 90221, Indonesia \\ ${ }^{1}$ Department of Accounting, STIE AMKOP Makassar \\ Jl. Jl. Meranti No.1, Pandang, Kota Makassar, Sulawesi Selatan 90231, Indonesia \\ ${ }^{2,3,4}$ Department of Graduate Program Universitas Negeri Makassar \\ Jl. AP. Pettarani Makassar, Sulawesi Selatan, 90221, Indonesia \\ 1'abdul_karim@stieamkop.ac.id; ${ }^{2}$ imranmusa1962@gmail.com; ${ }^{3}$ krtenreng@yahoo.com; ${ }^{4}$ mazis@unm.ac.id
}

Received: $29^{\text {th }}$ January 2021/ Revised: $14^{\text {th }}$ March 2021/ Accepted: $17^{\text {th }}$ March 2021

\begin{abstract}
How to Cite: Karim, A., Musa, C. I., Sahabuddin, R., \& Azis, M. (2021). The increase of rural economy at Baraka sub-district through village funds. The Winners, 22(1), 89-95.
\end{abstract}

https://doi.org/10.21512/tw.v22i1.7013

\begin{abstract}
The research aimed to examine the allocation of Village funds during the COVID-19 global crisis pandemic as well as its benefits to Baraka Sub-district in Enrekang Regency, South Sulawesi Province. It has an area of $159,15 \mathrm{~km}^{2}$ or $8,91 \%$ of the accumulated total area of Enrekang Regency. The research applied was qualitative method with a descriptive analysis approach. It was carried out by collecting data and information from the population taken from 12 villages in the Baraka Sub-district. The results show that BUMDes (Village-owned Enterprises) fosters rural economic development for all village communities in Baraka Sub-district and supports national economic growth. In addition, Village funds is considered to become a support for meeting the economic needs of the community during the COVID-19 pandemic. It is expected that various economic recovery programs will continue, whether they become central, regional, or local village-scale programs, especially in 12 villages in Baraka Subdistrict.
\end{abstract}

Keywords: rural economic, village funds, BUMDes

\section{INTRODUCTION}

Baraka Sub-district is an Enrekang Regency that has a wide variety of potentials capable of increasing economic growth. One of the potentials in the Baraka Sub-district is Pulu' Mandoti endemic rice, which is the only endemic rice in Indonesia. The economic potential can be produced by local farmers, in Salukanan Village, which reaches 70 thousand tons every year. The potential for economic growth from the endemic rice sector in Pulu' Mandoti is considered quite good because the market price of this rice reaches Rp 50.000 per kilogram.

The strategy of institutionalizing rural community economic enterprises in Baraka Subdistrict is seen as important in improving the economy (Taufiqurokhman \& Andriansyah. 2018). The perspective of building the economic sovereignty of rural communities aims to strengthen the competitiveness and bargaining power of the economic objects of the community (Karim, 2020c), especially during the current Global Pandemic (Karim, 2020b). This institutionalization has also become a basic need that is structured and targeted when the national economic situation is experiencing inflation, due to COVID-19 (Karim, 2020e).

Referring to the principles, values, and opportunities (Fitriyani et al. 2018) for institutionalized economic development in rural areas, the strategic choice that can be developed by rural communities is Badan Usaha Milik Desa/BUMDes (Village-owned Enterprises) (Karim et al., 2020). This business is suitable to be applied in rural areas in all villages in the Baraka Sub-District area for the several reasons (Riskasari \& Tahir, 2019), namely: 1) The business has a clear and firm constitutional and legal foundation (Nasution, Erlina, \& Rujiman, 2018); 2) This is clearly stated in government policies at the national, regional, and village levels (Amri, 2019); 3) This position allows the government to strengthen the position of the (Husin, 2017) two forms of business institutions through its programs, both short-medium and longterm; 4) This institutional form requires explicitly 
the involvement of citizens as active actors in it (Adhayanto et al., 2019).

Based on aspects that are strongly influenced by the contextual situation (social, political, economic, and geographical) in Baraka Sub-district, the choice of community business institutional forms is of course very contextual to get budget allocations sourced from the village fund (Asni, Maryunani, \& Budi, 2013; Karim, 2020e). The benefits generated from the use of village funds are used to finance (Syahruddin \& Karim, 2020b). The development and empowerment of rural communities in order to live prosperously (Lubis \& Muda, 2018). The main objectives of the village funds are: 1) poverty alleviation in the village (Hehamahua, 2015), 2) the process of equitable development, 3) restraining the rate of urbanization for rural communities (Hambali \& Niode, 2019), and 4) the priority for rural sector development originating from village funds (Rimawan et al., 2020).

For example, if BUMDes is engaged in strengthening commodity production, it can also strengthen its downstream sector by diversifying or downstream products (Warsono \& Ruksamin, 2014). Increasing the economy in rural areas in Baraka Subdistrict in the aspects of production, productivity, and income for rural communities will certainly have a positive impact on the Baraka Sub-District government (Karim, 2020a, 2020d). Village funds should be allocated as much as possible to BUMDes institutions to drive the rural economy (Sumantara et al., 2019).

Based on the indicative ceiling of transfer funds to the village government in Baraka Sub-district for the 2021 budget, the Village funds is $\mathrm{Rp} 11,78$ billion (Syahruddin \& Karim, 2020c). Meanwhile, the village Fund Allocation from the Enrekang Regency government is $\operatorname{Rp~5,52~billion.~With~this~village~funds,~}$ the community can use it according to their needs to increase their productivity and improve the quality of life in the village (Yusuf et al. 2019). The realization of village funds supports economic activities in order to keep moving in the community despite the Global Pandemic (Syukur \& Karim, 2020).

\section{METHODS}

The research applies a qualitative methods with a descriptive analysis approach. Qualitative research intends to understand the phenomena experienced (Syahruddin \& Karim, 2019a) by research subjects. The research aims to examine the allocation of village funds and the benefits to village communities in Baraka Sub-district. A research location is a place where researchers can see the actual condition of the object to be studied in order to obtain accurate data.

The research method is carried out by collecting data and information from the population taken from 12 villages in the Baraka Sub-district. The data are classified to provide a conclusion from actual events about the benefits of allocating village funds in economic improvement for village communities.

\section{RESULTS AND DISCUSSIONS}

Building from the village is one of the government's commitments to bring just economic equality, which causes the amount of village funds continue to increase every year, including for those in recognition of the rights of indigenous people. To achieve economic equality, the distribution of village funds must be followed by strengthening village institutions, as well as openness in budget management which needs to be developed for improvement.

This can be seen from the large ceiling for allocating village funds to 12 villages in Baraka Subdistrict for the last six years, whose source comes from the State Revenue and Expenditure Budget.

Table 1 shows the amount of village fund allocation for all villages in the Baraka Sub-district sourced from the State Revenue and Expenditure Budget. Rp 3,36 billion is allocated in 2015, Rp 7,46 billion in 2016, and Rp 9,55 billion in 2017. Meanwhile, during the last three years, the budget allocation has continued to increase, namely $\mathrm{Rp} 10,33$ billion in 2018, Rp 12,69 billion 2019, and Rp 11,98 billion in 2020. This proves the governments' commitment in improving the welfare of rural communities based on the village sector.

The village law mandates that the goal of village development is to improve the welfare of rural communities and the quality of human life as well as alleviate poverty through meeting basic needs such as building village facilities and infrastructure, developing local economic potential, and utilizing natural resources and the environment in a sustainable manner. Being sustainable is for the village development to meet current needs without sacrificing the needs of future generations of villages.

The use of village funds is prioritized to finance the implementation of cross-sectoral programs and activities in the village development and empowerment of village communities and to provide maximum benefits to the village community in the form of improving the quality of life. Moreover, it is to increase welfare and reduce poverty, as well as to improve public services at the village level.

From 2015 to 2020, village funds in Baraka Subdistrict has focused on infrastructure development and provision of facilities (physical) as well as improving the quality of human resources (non-physical) in 12 villages in Baraka Sub-district.

Based on Table 2, the realization of the village fund budget is used in the 12 villages in Baraka Subdistrict. From 2015 to 2020 , the allocation of village funds in all villages of Baraka Sub-district remains more dominant in the physical development sector the infrastructure sector, and the provision of facilities than improving the quality of human resources.

In the last six years, the allocation of the State Revenue and Expenditure Budget in the Baraka Sub- 
Table 1 The Budget Ceiling for the Village Fund for the Last 6 Years in Baraka Sub-district

\begin{tabular}{lcccccc}
\hline Village name & \multicolumn{7}{c}{ Total budget ceiling } \\
\cline { 2 - 7 } & $\begin{array}{c}\text { 2015 year } \\
\text { (IDR) }\end{array}$ & $\begin{array}{c}\mathbf{2 0 1 6} \text { year } \\
\text { (IDR) }\end{array}$ & $\begin{array}{c}\mathbf{2 0 1 7} \text { year } \\
\text { (IDR) }\end{array}$ & $\begin{array}{c}\mathbf{2 0 1 8} \text { year } \\
\text { (IDR) }\end{array}$ & $\begin{array}{c}\text { 2019 year } \\
\text { (IDR) }\end{array}$ & $\begin{array}{c}\mathbf{2 0 2 0} \text { year } \\
\text { (IDR) }\end{array}$ \\
\hline Banti & 273.465 .000 & 615.046 .000 & 803.978 .000 & 755.398 .000 & 876.852 .000 & $888.345,000$ \\
Bone-Bone & 275.999 .000 & 619.094 .000 & 781.419 .000 & 958.495 .000 & 1.155 .745 .000 & 1.153 .471 .000 \\
Bontongan & 290.764 .000 & 648.276 .000 & 826.526 .000 & 791.439 .000 & 932.800 .000 & 950.638 .000 \\
Janggurara & 275.271 .000 & 616.919 .000 & 780.346 .000 & 777.840 .000 & 1.121 .229 .000 & 935.298 .000 \\
Kadingeh & 289.468 .000 & 646.737 .000 & 809.192 .000 & 981.500 .000 & 1.189 .892 .000 & 1.218 .722 .000 \\
Kendenan & 272.987 .000 & 613.183 .000 & 823.211 .000 & 970.217 .000 & 1.171 .683 .000 & 1.012 .207 .000 \\
Pandung Batu & 273.621 .000 & 615.685 .000 & 794.166 .000 & 769.082 .000 & 1.113 .242 .000 & 951.524 .000 \\
Parinding & 277.661 .000 & 621.320 .000 & 812.731 .000 & 934.489 .000 & 1.118 .760 .000 & 1.063 .723 .000 \\
Pepandungan & 287.328 .000 & 633.200 .000 & $774.892,000$ & 988.173 .000 & 1.200 .020 .000 & 1.027 .691 .000 \\
Perangian & 274.712 .000 & 614.932 .000 & 779.202 .000 & 927.244 .000 & 1.109 .491 .000 & 1.065 .001 .000 \\
Salukanan & 273.052 .000 & 609.291 .000 & 790.045 .000 & 755.477 .000 & 876.785 .000 & 911.186 .000 \\
Tirowali & 272.328 .000 & 609.250 .000 & 784.087 .000 & 720.824 .000 & 828.162 .000 & 810.627 .000 \\
\hline Total & $\mathbf{3 . 3 3 6 . 6 6 2 . 0 0 0}$ & $\mathbf{7 . 4 6 2 . 9 3 3 . 0 0 0}$ & $\mathbf{9 . 5 5 9 . 7 9 5 . 0 0 0}$ & $\mathbf{1 0 . 3 3 0 . 1 7 8 . 0 0 0}$ & $\mathbf{1 2 . 6 9 4 . 6 6 1 . 0 0 0}$ & $\mathbf{1 1 . 9 8 8 . 4 3 3 . 0 0 0}$ \\
\hline
\end{tabular}

Source: Ministry of Village of the Republic of Indonesia, 2021 (processed)

Table 2 The Use of Village Funds in Baraka Sub-district in All Villages from 2015-2020

\begin{tabular}{lccc}
\hline \multicolumn{1}{c}{ Village name } & \multicolumn{2}{c}{ Use of village funds in 2015 - 2020 } & $\begin{array}{c}\text { Total budget } \\
\text { (IDR) }\end{array}$ \\
\cline { 2 - 3 } & $\begin{array}{c}\text { Physical development } \\
\text { (IDR) }\end{array}$ & $\begin{array}{c}\text { Nonphysical development } \\
\text { (IDR) }\end{array}$ & \\
\hline Banti & 3.793 .185 .000 & 419.909 .000 & 4.213 .094 .000 \\
Bone-Bone & 4.471 .483 .450 & 472.737 .550 & 4.944 .221 .000 \\
Bontongan & 4.073 .849 .000 & 366.594 .000 & 4.440 .443 .000 \\
Janggurara & 4.085 .486 .000 & 421.414 .000 & 4.506 .900 .000 \\
Kadingeh & 4.355 .125 .500 & 780.385 .500 & 5.135 .511 .000 \\
Kendenan & 4.559 .904 .000 & 303.584 .000 & 4.863 .488 .000 \\
Pandung Batu & 4.261 .003 .000 & 224.808 .000 & 4.485 .811 .000 \\
Parinding & 4.492 .065 .000 & 286.619 .000 & 4.778 .684 .000 \\
Pepandungan & 4.542 .958 .000 & $368.343,000$ & 4.911 .301 .000 \\
Perangian & 4.700 .449 .000 & 70.133 .000 & 4.770 .582 .000 \\
Salukanan & 3.940 .579 .000 & 275.257 .000 & 4.215 .836 .000 \\
Tirowali & 3.704 .791 .000 & 320.487 .000 & 4.025 .278 .000 \\
\hline
\end{tabular}

Source: Processed data, 2021

district was Rp 55,29 billion. The infrastructure sector and the provision of facilities have $\mathrm{Rp} 50,98$ billion. Meanwhile, for the improvement of the quality of human resources, the allocation is quite minimal as it only reaches $\operatorname{Rp} 4,31$ billion.

The allocation of village funds must improve the life quality of rural communities that can contribute to improving welfare and poverty alleviation for village communities. In addition, village funds should be increasing human resources through labor-intensive activity programs that deal with unemployment problems in villages by creating new jobs.
The village income and expenditure budget are the responsibility of the village management holder to provide information about all village activities and implement program plans. The amount of budget allocation which allocated directly to the village is determined $10 \%$ of and outside the Regional Transfer (on top) fund in stages. Budget from the State Revenue and Expenditure Budget is calculated based on the number of villages and allocated according to the population, poverty rate, area size, and geographic difficulty level to improve welfare and equitable village development. 
Table 3 Village Income and Expenditure Budget for 2017-2020

\begin{tabular}{lccc}
\hline \multicolumn{1}{c}{ Village name } & \multicolumn{2}{c}{ Total village income and expenditure budget } \\
\cline { 2 - 4 } & $\begin{array}{c}\text { Income } \\
\text { (IDR) }\end{array}$ & $\begin{array}{c}\text { Expenditure } \\
\text { (IDR) }\end{array}$ & $\begin{array}{c}\text { Financing } \\
\text { (IDR) }\end{array}$ \\
\hline Banti & 5.120 .267 .207 & 5.069 .548 .902 & 83.281 .049 \\
Bone-Bone & 4.551 .119 .140 & $5,041.390 .533$ & 226.767 .701 \\
Bontongan & 5.258 .406 .583 & 5.311 .774 .372 & 53.367 .789 \\
Janggurara & 5.357 .446 .473 & 5.423 .032 .789 & 420.642 .746 \\
Kadingeh & 6.542 .657 .438 & 6.386 .578 .136 & 267.483 .498 \\
Kendenan & 5.759 .481 .094 & 5.696 .905 .089 & 137.423 .995 \\
Pandung Batu & 5.372 .073 .558 & 5.421 .364 .959 & 350.250 .888 \\
Parinding & 5.688 .370 .396 & 5.740 .793 .595 & 50.943 .199 \\
Pepandungan & 5.772 .623 .948 & 5.684 .581 .135 & 277.655 .187 \\
Perangian & 5.590 .763 .911 & 5.626 .459 .296 & 38.529 .857 \\
Salukanan & 4.523 .133 .062 & 4.523 .182 .707 & 160.049 .645 \\
Tirowali & 4.862 .003 .109 & 4.837 .133 .668 & 160.304 .559 \\
\hline Total & $\mathbf{6 4 . 3 9 8 . 3 4 5 . 9 1 9}$ & $\mathbf{6 4 . 7 6 2 . 7 4 5 . 1 8 1}$ & $\mathbf{2 . 2 2 6 . 7 0 0 . 1 1 3}$ \\
\hline
\end{tabular}

Source: Processed data, 2021

Table 3 shows the village income and expenditure budget in 12 villages of Baraka Subdistrict for the last 4 years. The income of $\mathrm{Rp} 64,39$ billion is still predominantly sourced from State Revenue and Expenditure Budget transfers, which is followed by the Regional Revenue and Expenditure Budget of Enrekang Regency. Meanwhile, the village's original income, local tax results, and others are relatively minimal.

The village income and expenditure in Baraka Sub-district comes from village original income, namely from business results, assets, selfhelp, participation and mutual assistance, and other legitimate village income. Village income also comes from transfers, namely village funds, part of regency regional tax results and regional retribution, village fund allocation, financial assistance from Enrekang Regency Regional Revenue and Expenditure Budget financial.

One of the instruments undertaken by the government to improve the economy in each village is the allocation of village funds which originate 100\% of the State Revenue and Expenditure Budget. With the provision of village funds, it is expected that the village will be more empowered. In addition, optimism and self-confidence will become a source of villagebased national economic growth. With village fund, two problems, at least, must be resolved in all villages of Baraka Sub-district.

Firstly, the solution is opening up new job vacancies since village fund is a work nature, especially in overcoming unemployment during the COVID-19 global crisis pandemic. The village government involves all components of the community and opens up access to new jobs for those affected by the termination of employment. Secondly, with the existence of village development, there will be significant economic movement to meet the needs of urban communities and increase the income of each head of a household in the village. The challenge is that almost every village in Baraka Sub-district in the last three years has received Rp 1 billion in funds (Karim et al., 2020). The figures vary, but the difference occurs to be quite insignificant with certain considerations from each village.

The goal of village fund is to provide social justice for all Indonesian people, especially in Baraka Sub-district. First, a large number of funds cannot have a significant impact on rural areas-based countries since the funds are intended for village development. The economic improvement in the village may not be quite significant on a national scale but it can grow the rural economy. Second, the problem with village funds lies in their irregularities. Besides, improper use will be a serious problem. Village funds must be used for the benefit of the village instead of for just a moment's sake as seen in the realization of village fund budget allocations in 12 villages of Baraka Sub-district.

In the dominant sector, the realization of village funds remains prioritizing the infrastructure sector and the provision of facilities to Rp 50,98 billion. The sector for improving the quality of human resources is considered minimal with only $\mathrm{Rp} 4,31$ billion from 2015-2020. It occurs different with the budget realization in Baraka since the village government still prioritizes physical development. The large funds for the village and the trust from central government in the village will immediately cause various problems.

Village governments must think more objectively in formulating work programs to achieve 
significant economic improvements for their villages, especially when Indonesia is having an economic recession due to COVID-19. On the other hand, there have been many cases of village funds misuse that have dragged the village headman to prison. Public oversight is considered weak and inversely proportional to the level of compliance with the use of funds according to government regulations. Weak supervision will lead to a higher possibility of village officials misusing village funds, thus supervision should be improved. There must be special handling in using village funds, so village officials will not be caught in problems.

The global crisis pandemic has had a significant impact on the rate of economic growth for a country. The Indonesian government through the Ministry of Finance has officially announced that the gross regional domestic product in all provinces in Indonesia is experiencing a deficit since November 2020, which certainly impacts the pace of the economy.

BUMDes is village economic institutions that have legitimacy from the state. It is very closely related to the community since this business entity is a service provider that involves all village communities in the process of planning, implementing, and evaluating activities to develop the economy in the village. The Ministry of Villages of the Republic of Indonesia classifies the status of villages in Indonesia into the category of developing villages' index into five groups, namely: 1) highly ranked villages, 2) underdeveloped villages, 3) developing villages, 4) developed villages, and 5) independent villages. The status of village development index in 12 villages of Baraka District and the existence of village economic institutions can be seen in Table 4 .

Table 4 shows that all 12 villages are still in developing villages. Of all the existing superior village products, it shows that products in Baraka are mainly based in the agricultural sector. The allocation of village funds in 12 villages of Baraka is

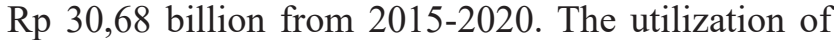
village economic institutions in improving the village economy is still running optimally, as stated in the village income and expenditure budget.

All villages still rely on two main incomes. First, village funds sourced from the State Revenue and Expenditure Budget. Meanwhile, the secondlargest village income and expenditure budget comes from the allocation of village funds from the Regional Income and Expenditure Budget of Enrekang Regency.

The village potentials in Baraka can be managed properly and will increase the village's original income if BUMDes is utilized. The role of the currently existing village government remains prioritizing infrastructure development and provision of facilities in the realization of village fund expenditures and the allocation of village funds. More specifically, BUMDes is one of the village institutions engaged in the socio-economic field. BUMDes functions as a service provider, especially to village communities, where the main focus is on the business sector in the village.

It is necessary to increase the socio-economic activities of rural communities in supporting urban economic movements. Central government programs through increasing the national economy can be realized by optimizing the role of BUMDes.

The existence of BUMDes in rural economic development for all village communities in Baraka supports national economic growth. The economy of the village community in the district should improve to be better than the village's original income from 20152020. There should have been a significant economic increase due to the village funds from the Central Government and the allocation of village funds from the Enrekang Regency Government.

Table 4 The Status of Developing Village Index in Baraka Sub-district

\begin{tabular}{lccc}
\hline \multicolumn{1}{c}{ Village name } & Village status & Village economic institutions & Village superior product \\
\hline Banti & Developing & BUMDes & Horticulture \\
Bone-Bone & Developing & BUMDes & Rice \\
Bontongan & Developing & BUMDes & Rice \\
Janggurara & Developing & BUMDes & Horticulture \\
Kadingeh & Developing & BUMDes & Clove \\
Kendenan & Developing & BUMDes & Rice \\
Pandung Batu & Developing & BUMDes & Rice \\
Parinding & Developing & BUMDes & Horticulture \\
Pepandungan & Developing & BUMDes & Rice \\
Perangian & Developing & BUMDes & Horticulture \\
Salukanan & Developing & BUMDes & Rice \\
Tirowali & Developing & BUMDes & Rice \\
\hline
\end{tabular}

Source: Processed data, 2021 


\section{CONCLUSIONS}

Restoration of village social and economic conditions certainly needs to be a focus, which is in line with the national economic recovery agenda. In addition, it is also important to adapt new habits to conditions that have changed drastically due to COVID-19 pandemic. The joint effort to revive itself will certainly not only be the work of the central or regional governments but all levels of society, including rural communities. Thus, it is essential that the various programs which will run in 2021 restore economic conditions.

The impact of the global crisis pandemic is devastating for social and economic life, especially for villages that drive the economy through village tourism activities. The COVID-19 pandemic tremendously hits not only tourism as the main destination of the region, but also tourist villages. Various economic recovery programs are expected to continue, whether they become central, regional, or local village-scale programs, especially in 12 villages of Baraka.

Especially for local villages, village communities will be greatly helped through various programs from village funds. Village funds are one of the hopes that economic recovery can take place quickly on target. During the pandemic, village funds are considered to have become a support in improving the economic needs of the community.

\section{REFERENCES}

Adhayanto, O., Arianto, B., Winatawira, W., Suryadi, S., \& Nurhasanah, N. (2019). The evaluation of the utilization of the 2018 village funds in Bintan district and Lingga district. Jurnal Bina Praja: Journal of Home Affairs Governance, 11(2), 125-136. https:// doi.org/10.21787/jbp.11.2019.125-136

Amri, K. (2019). Bumdes acceleration towards Mandiri village. Iapa Proceedings Conference, 268-281. https://doi.org/10.30589/proceedings.2019.236

Asni, F., Maryunani, S., \& Budi, D. (2013). The management of the village funds allocation as an instrument towards economic independence village (Case studies in 2 villages in Siak Regency, Province Riau). Journal of Business and Management, 10(4), 1-9. https://citeseerx.ist.psu.edu/viewdoc/downl oad? doi=10.1.1.1041. 1580\&rep=rep1\& typ e=pdf

Fitriyani, L. Y., Marita, M., Windyastuti, W., \& Nurahman, R. W. (2018). Determinants of village fund allocation. Jurnal Akuntansi Multiparadigma, 9(3), 526-539. http://dx.doi.org/10.18202/jamal.2018.04.9031

Hambali, I. R. \& Niode, I. Y. (2019). Improvement of village productive economy through village funds financing. International Journal of Applied Business and International Management, 4(3), 104-112. https://doi.org/10.32535/ijabim.v4i3.688

Hehamahua, H. (2015). Impact analysis of the village fund allocation (ADD) toward economic community (Case study on the rural district of Namlea Siahoni),
Buru Regency. Journal of Social and Development Sciences, 6(3), 15-23. https://doi.org/10.22610/jsds. v6i3.847

Husin, D. (2017). Flexibility of budget accountability using flow modification in the design of village financial accounting. Asia Pacific Fraud Journal, 1(1), 19-35. http://dx.doi.org/10.21532/apfjournal.v1i1.2

Karim, A. (2020a). The role of BUMDes as supporting regional economy in Enrekang Regency based on local wisdom. https://www.academia.edu/43785786/ The_Role_of_BUMDes_as_Supporting_Regional_ Economy_in_Enrekang_Regency_Based_on_ Local Wisdom

Karim, A. (2020b). BUMDes as a solution for food stock preparation and national economic buffer in the "Covid-19” global pandemic period. https://www. academia.edu/43739231/BUMDes_as_a_Solution for_Food_Stock_Preparation_and $\overline{\text { National }}$ Economic_Buffer_in_the_Covid_19_Global_ Pandemic Period

Karim, A. (2020c). Indonesia's economic revival behind the lockdown of 59 Countries. International Journal of Scientific \& Engineering Research, 11(9), 1385 - 1388. https://www.ijser.org/researchpaper/ Indonesias-Economic-Revival-Behind-theLockdwon-of-59-Countries.pdf

Karim, A. (2020d). Endemic rice Pulu' Mandoti supports the economy and food security at Salukanan community during Covid-19 global pandemic crisis. International Journal of Innovative Science and Research Technology, 5(9), 793-796. https://ijisrt. com/assets/upload/files/IJISRT20SEP485.pdf

Karim, A. (2020e). The agricultural sector is a pillar of economic growth during the Covid-19 pandemic after the ratification of the Omnibus Law Job Creation in Indonesia. https://www.academia.edu/44276897

Karim, A., Musa, C. I., \& Romansyah Sahabuddin, M. A. (2020). Regional economic growth the role of BUMDes institutions in Enrekang Regency. International Journal of Creative Research Thoughts, 8(11), 225-229. https://doi.org/10.6084/ m9.doi.one.IJCRT2011027

Lubis, A. \& Muda, I. (2018). Analysis of ownership and stock composition of Vocational Business Enterprises (BUMDES) and its impact on "Omset" of business owned enterprises. $1^{\text {st }}$ Economics and Business International Conference 2017 (EBIC 2017). Atlantis Press. https://doi.org/10.2991/ebic17.2018.43

Nasution, F. A., Erlina, \& Rujiman. (2018). The role of village funds to the development area in the subdistrict of West Bilah, Labuhanbatu Regency, North Sumatera, Indonesia. International Journal of Progressive Sciences and Technologies, 6(1), 221227. http://dx.doi.org/10.52155/ijpsat.v6.1.224

Riskasari, R. \& Tahir, N. (2019). Collaboration of development actors in realizing Mandiri villages in Bongki Lengkese Village, East Sinjai District, Sinjai District. Jurnal Ilmiah Ilmu Administrasi Publik, 8(2), 121-126. https://doi.org/10.26858/jiap. v8i2.7880 
Rimawan, M., Alwi, A., Ismunandar, I., \& Aryani, F. (2020). Village fund allocation on economic growth, human development index and poverty. Proceedings of the $1^{\text {st }}$ Annual Conference on Education and Social Sciences (ACCESS 2019), 338-342. Atlantis Press. https://www.atlantis-press.com/article/125943813. pdf

Sumantara, K., Suryani, K., Widnyana, I. W., Menes, C. C., Sutrisna, I. B. P., Oktariana, \& Dana, R. S. (2019). Swot analysis of Village Owned Enterprises (BUMDes) trading business of “Ayu Bagia” goods in Baha Village-Kecamatan Mengwi Badung District-Bali. International Journal of Sustainability, Education, and Global Creative Economic (Ijsegce), 2(1), 15-20. https://journals.segce.com/index.php/ IJSEGCE/article/view/51

Syahruddin \& Karim, A. (2019a). The effect of "Axis Hits Bonus" version tagline advertising and ambassador brand against Axis cards awareness. Proceedings of the First International Conference on Materials Engineering and Management-Management Section (ICMEMm 2018). Atlantis Press. https://doi. org/10.2991/icmemm-18.2019.13

Syahruddin \& Karim, A. (2020b). The role of cooperatives in economic growth in Makassar City during the Covid-19 Pandemic. International Journal of Innovative Science and Research Technology, 5(10), 334-337. https://www.researchgate. net/publication/344803916_The_Role_of_ Cooperatives_in_Economic_Growth_in_Makassar_ City_During_the_Covid-19_Pandemic
Syahruddin \& Karim, A. (2020c). The agricultural sector sustains the economy of Enrekang Regency during pandemic Covid-19. International Research Journal of Advanced Engineering and Science, 5(4), 161-165. https://www.researchgate.net/ publication/345898688_The_Agricultural_Sector_ Sustains_the_Economy_of_Enrekang_Regency_during_Pandemic_Covid-19

Syukur, A. \& Karim, A. (2020). Unemployment rate in South Sulawesi since the global crisis pandemic. International Journal of Innovative Science and Research Technology, 5(12), 259-2637. https://bit. ly/3ajzcXq

Taufiqurokhman, T. \& Andriansyah, A. (2018). Implementation of allocation of village funds (ADD) increases institutional and Ngombakan Village development programs manifest good governance. Matra Pembaruan: Jurnal Inovasi Kebijakan, 2(3), 197-206. https://doi.org/10.21787/mp.2.3.2018.197206

Yusuf, S., Umanailo, M. C. B., Putri, R. N., Qhuril, D., Ely, M., \& Darma, D. (2019). Village institution relations in the utilization of village funds in Namlea district. International. Journal of Scientific \& Technology Research, 8(8), 1837-1842. https://www.ijstr.org/ final-print/aug2019/-Village-Institution-RelationsIn-The-Utilization-Of-Village-Funds-In-NamleaDistrict.pdf

Warsono, H. \& Ruksamin, D. (2014). The obstacles of implementation of village allocation fund program in the North Konawe Southeast Sulawesi. Journal of Management and Sustainability, 4(3), 175-183. https://doi.org/10.5539/jms.v4n3p175 